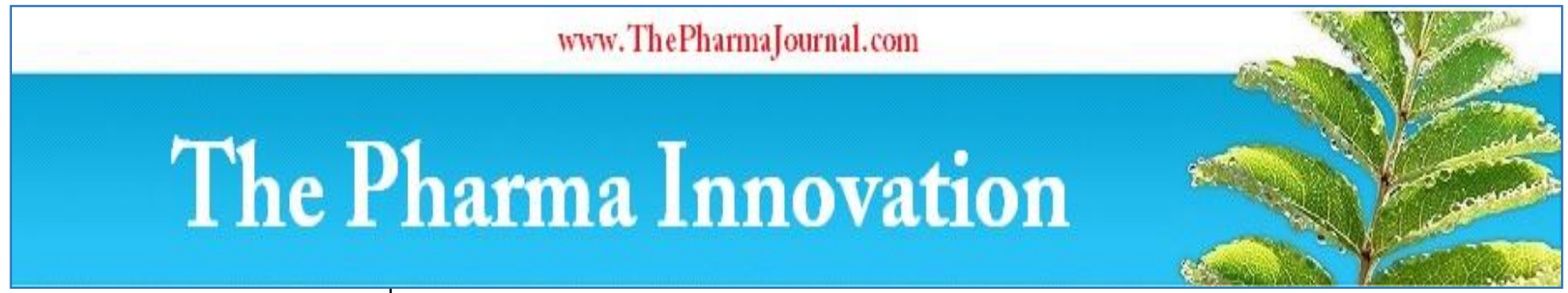

ISSN (E): 2277 - 7695

ISSN (P): 2349-8242

NAAS Rating: 5.23

TPI 2021; 10(4): 466-470

(C) $2021 \mathrm{TPI}$

www.thepharmajournal.com

Received: 07-01-2021

Accepted: 06-02-2021

Kairovin Lakra

Research Scholar, Department of Agronomy, CSAUAT, Kanpur,

Uttar Pradesh, India
Corresponding Author:

Kairovin Lakra

Research Scholar, Department of Agronomy, CSAUAT, Kanpur,

Uttar Pradesh, India

\title{
Broad leaf weed management in wheat by pre- emergence and pre-mix post-emergence combinations of herbicides under different irrigation schedule
}

Kairovin Lakra

DOI: https://doi.org/10.22271/tpi.2021.v10.i4g.5984

\section{Abstract}

A 2-years study was conducted to assess the impact of irrigation schedule and weed management practices on broad leaf weed (BLW) flora and wheat dry matter production. Experiments were conducted during Rabi season of 2017-18 to 2018-19 at CSAUAT, Kanpur under split-plot design with four replication having four irrigation regimes were assigned to main plots and eight weed management practices were allocated to sub plots. Irrigations at crown root initiation (CRI) and active tillering stage $\left(\mathrm{I}_{1}\right)$ significantly reduce the density and weight of BLW with highest WCE and crop resistance index (CRI) over other irrigation regimes. However, irrigation at CRI+ jointing+ booting + flowering+ milking stage $\left(\mathrm{I}_{4}\right)$ recorded highest weed effectiveness (WE) and dry matter yield (CDMY) followed by irrigation at CRI + active tillering + booting + flowering stage $\left(\mathrm{I}_{3}\right)$. All the weed management treatments significantly reduced the density and weight of BLW resulted maximum crop dry matter yield over weedy check. Among herbicidal treatments, lowest density, fresh and dry weight of BLW, WE and the highest WCE, CRI, WPI and CDMY was recorded with the application of broadway (carfentrazone ethyl $20 \%+$ sulfosulfuron $25 \% \mathrm{WG}) 100 \mathrm{~g} \mathrm{ha}^{-1}$ at 35 DAS and it was statistically at par with clodinafoppropagyl $15 \%+$ metsulfuron $1 \% 400 \mathrm{~g} \mathrm{ha}^{-1}$ at 35 DAS.

Keywords: CRI, Irrigation, Herbicides, BLW, WCE, WPI, WE, Wheat

\section{Introduction}

Wheat (Triticum aestivum L.) is the most widely cultivated food grain crop of world playing crucial role in global food security by providing food to billions of people and half of the dietary protein and more than half of the calories (Meena et al., 2017) ) $^{[3]}$. It is the second important food crop consumed next to rice and contributes to the extent of $25 \%$ of total food grain production of country. In era of climate change and increasing biotic and abiotic stresses, maintaining yield up to required level is going to be formidable challenge in coming future (Deshmukh et al., 2020) ${ }^{[2]}$. Wheat productivity depends on the several factors like establishment techniques, irrigation, weed management, nutrients management and other cultural practices (Singh et al., 2013 and Singh et al., 2020) ${ }^{[9,10]}$. Weeds are the major deterrent to the development of sustainable wheat crop production and causes enormous losses (37.0 to $57.1 \%$ ) due to their interference (Verma et al., 2015) ${ }^{[15]}$. Wheat generally sown after pre-sowing irrigation to obtain the uniform germination and initial establishment, but at the same time irrigation favours the weed seed germination. Under such condition, it is very essential to control weeds up to 45 DAS (Singh et al., 2009) ${ }^{[6]}$. Weed competition for longer period results into reduction of crop growth and yield attributes over weed free environment (Yadav et al., 2020) ${ }^{[19]}$.

Herbicides offer most ideal, practical, effective and economical means of reducing early weed competition and crop production losses. Various researchers have investigated the efficacy of different herbicides for control of weeds in wheat crop mostly targeting grassy weeds. But in those areas where the problem of grassy weeds not of too much, alternate herbicides have to be used. In the central parts of Uttar Pradesh, it has been reported that various weed species viz. Anagallis arvensis, Vicia sativa, Lathyrus aphaca, Spergula arvensis, Chenopodium album, Chenopodium murale, Vicia hirsuta, Rumex spp. Melilotus spp., Solanum nigrum, Fumaria parviflora and Euphorbia spp. are the notorious weeds adversely affecting wheat crop (Verma et al., 2007, Verma et al., 2008, Verma, 2014, Singh et al., 2017 and Yadav et al., 2020) [11,13, $16,18,19]$. Severe problem of Solanum nigrum and Physalis minima were also reported from various wheat growing parts of the country. Broad leaved weeds posed a severe problem in 
central parts of Uttar Pradesh just like of grassy weeds. In this region, farmers mostly depend on 2, 4-D, which is not always very effective against broad leaf weeds. For control of broadleaf weeds in wheat, three major herbicides used in India are metsulfuron, 2, 4-D and carfentrazone. However, continuous use of these herbicides leads to built up of resistance in weeds. To broaden the spectrum of weed kill and to provide the long term residual weed control, it is therefore, necessary to combine or change the method and strategies of weed control are advocated. Combined use of herbicide besides providing control of complex weed flora will also help in managing and delaying the herbicide resistance problem. Hence, the present investigation was undertaken with the objectives to study the broad-leaved weed flora in wheat and to study the comparative efficacy of various herbicides for controlling broad-leaved weeds in wheat under different irrigation schedule.

\section{Materials and Methods}

To evaluate the effect of irrigation regimes and combined use of herbicides on existence of broad leaf weeds (BLW) and crop dry matter yield of wheat crop, this investigation was conducted during Rabi season 2017-18 and 2018-19 at Students Instructional Farm of Chandra Shekhar Azad University of Agriculture and Technology, Kanpur (U.P). The farm is situated between Latitudes $26^{\circ} 20^{\prime \prime}$ and $26^{\circ} 35^{\prime} \mathrm{N}$ and Longitudes $80^{\circ} 18^{\prime}$ and $80^{\circ} 35^{\prime} \mathrm{E}$ and having an altitude of $125.9 \mathrm{~m}$ above sea level. Kanpur's climate is classified as warm and semi-arid. The soil of experimental field was sandy loam (Inceptisols) shallow, flat, well drained and moderately fertile, being low in available organic carbon $(0.35 \%)$, available nitrogen $\left(172.4 \mathrm{~kg} \mathrm{ha}^{-1}\right)$, sulphur $\left(15.7 \mathrm{~kg} \mathrm{ha}^{-1}\right)$ and zinc $(0.456 \mathrm{ppm})$, and medium in available phosphorus (12.8 $\mathrm{kg} \mathrm{ha}^{-1}$ ) and potassium (156.5 $\left.\mathrm{kg} \mathrm{ha}^{-1}\right)$. A composite sample from each plot, $0-30 \mathrm{~cm}$ of soil depth, was collected and analyzed before sowing. The experiment was laid out in Split Plot Design and replicated four times having 32 treatment combinations. Treatments consisted of four irrigation schedule viz. irrigation at CRI and active tillering stage $\left(\mathrm{I}_{1}\right)$, irrigation at CRI + jointing + booting $\left(\mathrm{I}_{2}\right)$, CRI + active tillering + booting + flowering stage $\left(\mathrm{I}_{3}\right)$ and irrigation at CRI + jointing + booting + flowering + milking stage $\left(\mathrm{I}_{4}\right)$ were assigned to main plots and weed management practices viz. $\mathrm{W}_{1}$-weedy check, $\mathrm{W}_{2}$-two hand weeding at 20 and 40 DAS, $\mathrm{W}_{3}$-sulfosulfuron $25 \mathrm{~g} \mathrm{ha}^{-1}$ at $35 \mathrm{DAS}, \mathrm{W}_{4^{-}}$pendimethalin

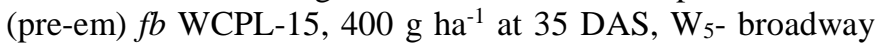
(carfentrazone ethyl 20\% + sulfosulfuron 25\%WG) $100 \mathrm{~g} \mathrm{ha}^{-1}$ at 35 DAS, $\mathrm{W}_{6}$ - halauxafen + penxasulam $23.5 \%, 75 \mathrm{~g} \mathrm{ha}^{-1}$ at 35 DAS, $\mathrm{W}_{7}$ - halauxafen - methyl $1.21 \% \mathrm{w} / \mathrm{w}+$ fluroxypyr at 35 DAS and $\mathrm{W}_{8^{-}}$clodinafop- propargyl $15 \%+$ metsulfuron $1 \%, 400 \mathrm{~g} \mathrm{ha}^{-1} 35$ DAS were allocated to sub plots. The experimental crop was sown in lines $22.5 \mathrm{~cm}$ a part using 100 $\mathrm{kg} \mathrm{ha}^{-1}$ seed by opening slits with seed-drill machine. All the herbicides were applied as per the treatments with the help of foot sprayer fitted with flat fan nozzle. The spray volume was 500 litres water/ha. Half amount of nitrogen and full dose of phosphorus and potash were applied as basal at the time of sowing, $1 / 4$ part of nitrogen was top dressed after first irrigation and remaining $1 / 4$ part of nitrogen was top dress at spike initiation stage. The nitrogen, phosphorus and potassium were applied in the form of urea, single super phosphate and murate of potash, respectively. All the agronomic practices were done for the success of crop.
An area of $0.25 \mathrm{~m}^{2}$ was selected randomly at three spots by throughing a quadrate of $0.5 \times 0.5 \mathrm{~m}$, weed species were counted from that area, and density (No. $\mathrm{m}^{-2}$ ) was taken at 60 and 90 DAS. Absolute density of BLW was calculated with the help of following formula:

$$
\text { Absolute density }(\mathrm{AD})=\frac{\text { Total number of individuals of a species in all quadrats }}{\text { Total number of quadrats employed }}
$$

The BLW inside the quadrate were counted and the average of three quadrates was taken. The actual values were subjected to square root transformation $\sqrt{(\mathrm{x}+1)}$ for analysis. The BLW present within the quadrate from each plot were taken for fresh and dry matter accumulation. These samples were first dried under the sun and then kept in oven at $70 \pm 5^{\circ} \mathrm{C}$ until a constant weight was achieved. The dried samples were weighed and the final dry weight of BLW was expressed as $\mathrm{g}$ $\mathrm{m}^{-2}$. WCE was calculated at 30, 60 and 90 DAS using following formula:

$$
\text { W.C.E. }(\%)=\frac{\text { D.M.C }- \text { D.M.T. }}{\text { D.M.C. }} \times 100
$$

Where, D.M.C. =Dry matter production of BLW per unit area in weedy check. D.M.T. = Dry matter production of BLW per unit area in the treatment to be compared. CRI of $\mathrm{BLW}$ are calculated using following formula:

$$
\mathrm{CRI}=\frac{\begin{array}{l}
\text { Dry matter production by } \\
\text { the crop in treated plot }
\end{array}}{\begin{array}{l}
\text { dry matter production by } \\
\text { the crop in control plot }
\end{array}} \times \frac{\begin{array}{l}
\text { Dry matter production of } \\
\text { weed in control plot }
\end{array}}{\begin{array}{l}
\text { Dry matter production of } \\
\text { weed in treated plot }
\end{array}}
$$

Weed persistence index are calculated by using following formula:

$$
\begin{aligned}
& \text { Dry weightof weeds Weed density in } \\
& \mathrm{WMI}=\frac{\text { in treatedplot }}{\text { Dry weightof weeds }} \times \frac{\text { control plot }}{\text { Weed density in }} \\
& \text { in control plot treated plot }
\end{aligned}
$$

BLW effectiveness was calculated by using the formula as suggested by U.S.D.A/I.C.A.R. A.I.C.R.P.W.C. (1988). It refers to the number of weed in treatment plot to the number of weeds in weedy plot.

$$
\text { Weed effectiveness }(\%)=\frac{\begin{array}{c}
\text { Number of weed in } \\
\text { treatment plot }
\end{array}}{\begin{array}{c}
\text { Number of weed in } \\
\text { weedy plot }
\end{array}} \times 100
$$

After complete sun drying, harvested produce of each net plot were weighed for biological yield and converted in terms of $\mathrm{kg} \mathrm{ha}{ }^{-1}$. For statistical analysis "Analysis of variance" technique was applied to the data recorded for each character. Overall differences were tested by " $F$ " test of significance at $5 \%$ level of significance. Critical differences at 5\% level of probability were worked out for comparing the treatments. 


\section{Results and Discussion}

\section{Effect on density of broad leaf weeds (BLW)}

On an average of two years study, Chenopodium album, Anagallis arvensis, Melilotus indica, Rumex denticulate and Vicia sativa was the major broad leaf weeds (BLW) recorded under weedy check. This can be discussed in light of the fact that the experimental field was under continuous black gramwheat, toria-wheat and rice-wheat sequence during previous years resulting in uniform distribution of weed seeds over entire area of experiment (Singh et al., 2020 and Verma et al., 2007) ${ }^{[10,14]}$. Singh et al. (2015) [7], Verma et al. (2017) ${ }^{[13]}$, Singh et al. (2017) ${ }^{[11]}$ and Yadav et al. (2020) ${ }^{[19]}$ was also observed similar association of broad leaf weeds in wheat crop.

The density of BLW was increased up to 60 DAS and thereafter a decreasing trend was noticed, irrespective of irrigation and the herbicides application (Table 1). It might be due to the fact that at later stages, growth of weeds ceased due to senescence and completion of life cycle. The density of BLW was recorded under different irrigation schedule and herbicidal treatments were significantly reduced as compare to weedy check. Population of BLW significantly decreased with the decrease in irrigation frequency. Among irrigation schedule, application of irrigation at CRI + jointing + booting + flowering + milking stage $\left(\mathrm{I}_{4}\right)$ recorded significantly the highest density of BLW fb same density of LBW was with irrigation at irrigation at CRI + active tillering + booting + flowering stage $\left(\mathrm{I}_{3}\right)$. The increase in density of BLW at higher rate of irrigation resulted from the greater availability of soil moisture (Singh et al., 2009, Verma, 2014, Verma et al., 2007) $[8,18,17]$. Decrease in the number of irrigation significantly decreased the density of BLW (Singh et al., 2015) ${ }^{[7]}$. Application of irrigation at CRI and active tillering stage $\left(\mathrm{I}_{1}\right)$ was recorded significantly lowest density of grassy weeds as compared to other irrigation treatments. The decrease in weed density at lower rate of irrigation was the result of inadequate supply of soil moisture (Verma et al., 2017) ${ }^{[13]}$.

All the weed management practices significantly reduced the population of BLW as compared to weedy check. However, hand weedings at 20 and 40 DAS (weed free) was found more effective than the herbicidal treatments, due to slow pace of growth of first flush of weeds at 20 days after sowing thereafter the emergence of new flushes of weeds could not attain full growth under the shade of crop plants (Verma et al., 2008, Verma, 2014, Singh et al., 2015) ${ }^{[16,18,7]}$. Among herbicidal treatments, an application of broadway (carfentrazone- ethyl 20\% + sulfosulfuron 25\% WG) $100 \mathrm{~g}$ $\mathrm{ha}^{-1}$ at 35 DAS was significantly reduced the density of BLW as compared to other treatments and it was statistically at par with clodinafop- propagyl $15 \%+$ metsulfuron $1 \% 400 \mathrm{~g} \mathrm{ha}^{-1}$ at 35 DAS. Sequential application of pendimethalin (pre-em) fb WCPL-15 $400 \mathrm{~g} \mathrm{ha}^{-1}$ at 35 DAS; and the combined application halauxafen + penxasulam $23.5 \% 75 \mathrm{~g} \mathrm{ha}^{-1}$ at 35 DAS and halauxafen $1.21 \% \mathrm{w} / \mathrm{w}+$ fluroxpyr at $35 \mathrm{DAS}$ significantly superior over weedy check. However, alone application sulfosulfuron $25 \mathrm{~g} \mathrm{ha}^{-1}$ at 35 DAS significantly superior over weedy check but found least effective against BLW as compared to combined application of herbicides. Excellent control of BLW in wheat was achieved with the tank or ready mix application of herbicides as compare to their alone application was also reported by Singh et al. (2020) ${ }^{[10]}$ and Yadav et al. (2020) ${ }^{[19]}$.
Fresh and dry weight of broad leaf weeds (BLW)

The fresh and dry weight of BLW were recorded under different irrigation was significantly reduced as compare to weedy check (Table 1). The maximum fresh and dry weight of BLW was recorded with the application of irrigation at CRI + jointing + booting + flowering + milking stage $\left(\mathrm{I}_{4}\right)$ followed by irrigation at irrigation at CRI + active tillering + booting + flowering stage $\left(\mathrm{I}_{3}\right)$, which supply sufficient soil moisture to weeds. Among irrigation schedule, irrigation at CRI and active tillering stage $\left(\mathrm{I}_{1}\right)$ was recorded significantly the lowest fresh and dry weight of BLW as compared to other irrigation schedule. Results are close conformity with the results of Verma (2014) ${ }^{[18]}$ and Verma et al. (2017) ${ }^{[13]}$ he was also recorded similar variation in weed weight at different irrigation frequency. Reduction in the fresh and dry weight of BLW was observed under lower number of irrigation due to inadequate supply of moisture (Tunio et al., 2020, Verma et al., 21015) ${ }^{[12,15]}$.

All the weed control treatments significantly reduced fresh and dry weight of BLW as compared to weedy check at different crop growth stages. It was observed that the combined application of herbicide had significant advantage over alone application to control BLW. The lowest fresh and dry weight of BLW was observed with broadway (carfentrazone- ethyl 20\% + sulfosulfuron 25\% WG) $100 \mathrm{~g}$ $\mathrm{ha}^{-1}$ at 35 DAS fb clodinafop- propagyl $15 \%+$ metsulfuron $1 \% 400 \mathrm{~g} \mathrm{ha}^{-1}$ at $35 \mathrm{DAS}$, pendimethalin (pre-em) fb WCPL$15400 \mathrm{~g} \mathrm{ha}^{-1}$ at 35 DAS, halauxafen + penxasulam $23.5 \% 75$ $\mathrm{g} \mathrm{ha}^{-1}$ at 35 DAS, sulfosulfuron $25 \mathrm{~g} \mathrm{ha}^{-1}$ at 35 DAS and halauxafen $1.21 \% \mathrm{w} / \mathrm{w}+$ fluroxpyr at 35 DAS, respectively. All the herbicide treatments significantly decreased the fresh and dry weight of BLW (Singh et al., 2013, Singh et al., 2017 and Singh et al., 2015) [9, 11, 7]. None of the herbicidal treatments as effective as hand weeding at 20 and 40 DAS (Singh et al., 2009, Yadav et al., 2020 and Verma et al., 2007) [8, 19, 18]. Singh et al. (2020) ${ }^{[10]}$ was reported the superiority of hand weeding over herbicidal treatments.

\section{Weed control efficiency (WCE)}

Irrigation at CRI and active tillering stage $\left(\mathrm{I}_{1}\right)$ was recorded highest WCE of BLW as compare to $\mathrm{I}_{4}$ (irrigation at CRI + jointing + booting + flowering + milking), $\mathrm{I}_{3}$ (irrigation at CRI + active tillering + booting + flowering) and $\mathrm{I}_{2}$ (irrigation at CRI + jointing + booting), respectively (Table 2 ). Reduction in the number of irrigation increases the weed control efficiency was also reported by Verma (2014) ${ }^{[18]}$, Verma et al. (2015) ${ }^{[15]}$ and Verma et al. (2017) ${ }^{[13]}$.

An application of broadway (carfentrazone- ethyl 20\%+ sulfosulfuron $25 \% \mathrm{WG}) 100 \mathrm{~g} \mathrm{ha}^{-1}$ at 35 DAS was recorded the highest weed control efficiency of BLW fb the WCE with clodinafop- propagyl $15 \%$ + metsulfuron $1 \% 400 \mathrm{~g} \mathrm{ha}^{-1}$ at 35 DAS. Among herbicidal treatments, the lowest weed control efficiency of BLW was recorded in plots treated with sulfosulfuron $25 \mathrm{~g} \mathrm{ha}^{-1}$ at 35 DAS followed by sequential application of pendimethalin (pre-em) fb WCPL-15 $400 \mathrm{~g} \mathrm{ha}^{-1}$ at 35 DAS. Highest weed control efficiency indicate its relative performance of particular set of treatment (Singh et al., 2013, Verma et al., 2017 and Singh et al., 2015) ${ }^{[9,13,7] .}$ However, hand weeding at 20 and 40 DAS (weed free) treatments proved superiority over herbicidal treatments (Ansari et al., 2009 and Singh et al., 2020) ${ }^{[1,10] .}$

\section{Weed indices}

The maximum crop resistance index for BLW was recorded 
with irrigation at CRI+ active tillering stage over other irrigation schedule (Table 2). Whereas, weed persistence index and weed effectiveness index was the highest with the application of irrigation at CRI + jointing + booting + flowering + milking stage $\left(\mathrm{I}_{4}\right)$ and these were reduced with decreased in the number of irrigations.

Among herbicidal treatments, application of broadway (carfentrazone- ethyl 20\% + sulfosulfuron 25\% WG) $100 \mathrm{~g}$ $\mathrm{ha}^{-1}$ at 35 DAS was recorded maximum crop resistance index weed persistence index and the lowest weed effectiveness percentage as compared to clodinafop- propagyl $15 \%+$ metsulfuron $1 \% 400 \mathrm{~g} \mathrm{ha}^{-1}$ at $35 \mathrm{DAS}$, pendimethalin (preem) fb WCPL-15 $400 \mathrm{~g} \mathrm{ha}^{-1}$ at 35 DAS, halauxafen + penxasulam $23.5 \% 75 \mathrm{~g} \mathrm{ha}^{-1}$ at $35 \mathrm{DAS}$, halauxafen $1.21 \%$ $\mathrm{w} / \mathrm{w}+$ fluroxpyr at $35 \mathrm{DA}$ and sulfosulfuron $25 \mathrm{~g} \mathrm{ha}^{-1}$ at 35 DAS, respectively. Similar results are also reported by Rana et al. (2017) ${ }^{[4]}$ and Sharma et al. (2020) ${ }^{[5]}$.

\section{Crop dry matter yield}

Irrigation schedule showed significant influence on dry matter yield of wheat (Table 2). Irrigation at CRI + jointing + booting + flowering + milking stage $\left(\mathrm{I}_{4}\right)$ was recorded significantly the highest crop dry matter yield than $I_{1}$ and $I_{2}$ and it was statistically at par with $\mathrm{I}_{3}$. The better crop development and yield under frequent irrigation was the result of better soil moisture availability (Singh et al., 2010, Verma et al., 2017 and Tunio et al., 2020) [6,13,12].

Application of broadway (carfentrazone- ethyl 20\% + sulfosulfuron $25 \% \mathrm{WG}) 100 \mathrm{~g} \mathrm{ha}^{-1}$ at 35 DAS was recorded maximum dry matter yield fb clodinafop- propagyl $15 \%+$ metsulfuron $1 \% 400 \mathrm{~g} \mathrm{ha}^{-1}$ at $35 \mathrm{DAS}$, pendimethalin (preem) fb WCPL-15 $400 \mathrm{~g} \mathrm{ha}^{-1}$ at 35 DAS, halauxafen + penxasulam $23.5 \% 75 \mathrm{~g} \mathrm{ha}^{-1}$ at $35 \mathrm{DAS}$, sulfosulfuron $25 \mathrm{~g}$ $\mathrm{ha}^{-1}$ at $35 \mathrm{DAS}$ and halauxafen $1.21 \% \mathrm{w} / \mathrm{w}+$ fluroxpyr at 35 DAS, respectively. All the herbicidal treatments gave significantly higher dry matter yield as compared to weedy check. However, none of the herbicidal treatment as effective as hand weeding at 20 and 40 DAS, which recorded significantly maximum dry matter yield of wheat (Singh et al., 2015 and Verma et al., 2015) ${ }^{[7,15] .}$

Table 1: Effect of irrigation and herbicides on density, fresh and dry weight of broad leaf weeds (pooled data of two years)

\begin{tabular}{|c|c|c|c|c|c|c|c|c|}
\hline \multirow[t]{2}{*}{ Treatments } & \multicolumn{2}{|c|}{ Density $\left(\right.$ No. $\left.\mathrm{m}^{-2}\right)$} & \multicolumn{2}{|c|}{ Absolute density $\left(\right.$ No. $\left.\mathrm{m}^{-2}\right)$} & \multicolumn{2}{|c|}{ Fresh weight $\left(\mathrm{g} / \mathrm{m}^{2}\right)$} & \multicolumn{2}{|c|}{ Dry weight $\left(\mathrm{g} / \mathrm{m}^{2}\right)$} \\
\hline & 60 DAS & 90 DAS & 60 DAS & 90 DAS & 60 DAS & 90 DAS & 60 DAS & 90 DAS \\
\hline \multicolumn{9}{|l|}{ Irrigation schedule } \\
\hline I1-Two irrigation (CRI+ active tillering) & $47.9(6.99)$ & $43.0(6.64)$ & $16.0(4.12)$ & $14.4(3.92)$ & $44.7(6.76)$ & $40.1(6.41)$ & $13.9(3.86)$ & $12.4(3.66)$ \\
\hline $\mathrm{I}_{2}$-Three irrigation(CRI+ jointing+ booting) & $58.3(7.70)$ & $50.4(7.17)$ & $19.4(4.52)$ & $16.8(4.22)$ & $59.4(7.77)$ & $54.8(7.47)$ & $16.6(4.20)$ & $14.1(3.88)$ \\
\hline $\begin{array}{l}\mathrm{I}_{3} \text { - Four irrigation (CRI+ Active tillering+ } \\
\text { booting+ flowering) }\end{array}$ & $73.7(8.64)$ & $67.2(8.26)$ & $24.6(5.06)$ & $22.4(4.84)$ & $71.9(8.54)$ & $67.8(8.29)$ & $19.0(4.47)$ & $16.4(4.17)$ \\
\hline $\begin{array}{l}\text { I4-Five irrigation (CRI+ jointing+ booting+ } \\
\text { flowering+ milking) }\end{array}$ & $80.2(9.01)$ & $73.7(8.64)$ & $26.7(5.27)$ & $24.6(5.06)$ & $77.5(8.86)$ & $72.8(8.59)$ & $20.1(4.60)$ & $16.6(4.19)$ \\
\hline $\mathrm{CD}(\mathrm{P}=0.05)$ & 0.10 & 0.18 & 0.05 & 0.11 & 0.46 & 0.49 & 0.20 & 0.13 \\
\hline \multicolumn{9}{|l|}{ Herbicides } \\
\hline $\mathrm{W}_{1}$-Weedy check & 131.5(11.51) & $124.1(11.19$ & $43.9(6.70)$ & $41.4(6.51)$ & $134.5(11.64)$ & $125.7(11.3)$ & $45.0(6.78)$ & $42.9(6.62)$ \\
\hline $\mathrm{W}_{2-}$ Two hand weeding (20 and 40 DAS) & $\begin{array}{c}0.00 \\
(0.67) \\
\end{array}$ & \begin{tabular}{|c|}
0.00 \\
$(0.67)$ \\
\end{tabular} & $\begin{array}{c}0.00 \\
(0.67) \\
\end{array}$ & $\begin{array}{c}0.00 \\
(0.67) \\
\end{array}$ & $\begin{array}{c}0.00 \\
(0.67) \\
\end{array}$ & $\begin{array}{c}0.00 \\
(0.67) \\
\end{array}$ & $\begin{array}{c}0.00 \\
(0.67) \\
\end{array}$ & \begin{tabular}{|c|}
0.00 \\
$(0.67)$ \\
\end{tabular} \\
\hline 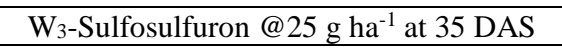 & $80.1(9.01)$ & $72.7(8.59)$ & $26.7(5.26)$ & $24.3(5.02)$ & $71.9(8.54)$ & $67.2(8.26)$ & $17.6(4.32)$ & $14.6(3.95)$ \\
\hline $\begin{array}{c}\text { W4- Pendimethalin (pre-em) } f b \text { WCPL- } \\
15 @ 400 \mathrm{~g} \mathrm{ha}^{-1} \text { at } 35 \text { DAS }\end{array}$ & $64.8(8.11)$ & $57.4(7.64)$ & $21.6(4.75)$ & 19.1(4.49) & $61.3(7.90)$ & $56.6(7.59)$ & 15.6() 4.07 & $12.5(6.68$ \\
\hline $\begin{array}{c}\text { W5-Broadway (carfentrazone ethyl 20\%+ }_{\text {5 }} \text { sulfosulfuron 25\%WG) @ } 100 \mathrm{~g} \text { a.i. } \mathrm{ha}^{-1} \text { at } \\
\text { 35 DAS }\end{array}$ & $42.9(6.62)$ & $35.5(6.04)$ & $14.3(3.91)$ & $11.8(3.58)$ & $48.8(7.06)$ & $44.1(6.72)$ & $13.3(3.78)$ & $10.2(3.35)$ \\
\hline $\begin{array}{l}\text { W6- Halauxafen + penxasulam } 23.5 \% \text { @ } 75 \\
\text { g a.i. ha }{ }^{-1} \text { at } 35 \text { DAS }\end{array}$ & $64.4(8.08)$ & $57.0(7.61)$ & $21.5(4.74)$ & $19.0(4.47)$ & $61.1(7.88)$ & $56.3(7.57)$ & $15.5(4.07)$ & $12.5(3.67)$ \\
\hline $\begin{array}{l}\mathrm{W}_{7-} \text { Halauxafen - methyl 1.21\% w/w + } \\
\text { fluroxypyr @ at 35 DAS }\end{array}$ & $81.4(9.08)$ & $74.0(8.66)$ & $27.1(5.30)$ & 24.7(5.07) & $72.8(8.59)$ & $68.0(8.31)$ & $17.8(4.34)$ & $14.7(3.97)$ \\
\hline $\begin{array}{l}\text { W8- Clodinafop- propargyl 15\%+ } \\
\text { metsulfuron 1\% @ 400 g a.i. ha }{ }^{-1} 35 \text { DAS }\end{array}$ & $55.2(7.50)$ & $47.8(6.99)$ & $18.4(4.40)$ & $15.9(4.12)$ & $56.5(7.58)$ & $52.8(7.33)$ & $14.6(3.95)$ & $11.5(3.54)$ \\
\hline $\mathrm{CD}(\mathrm{P}=0.05)$ & 0.07 & 0.14 & 0.03 & 0.06 & 0.21 & 0.22 & 0.09 & 0.06 \\
\hline
\end{tabular}

Table 2: Effect of irrigation and herbicides on indices of broad leaf weeds and yield of wheat (pooled data of two years)

\begin{tabular}{|c|c|c|c|c|c|c|c|c|c|}
\hline \multirow[t]{2}{*}{ Treatments } & \multicolumn{2}{|c|}{$\begin{array}{c}\text { WCE } \\
(\%)\end{array}$} & \multicolumn{2}{|c|}{$\begin{array}{c}\text { Crop resistance } \\
\text { index }\end{array}$} & \multicolumn{2}{|c|}{$\begin{array}{l}\text { Weed persistence } \\
\text { index }\end{array}$} & \multicolumn{2}{|c|}{$\begin{array}{c}\text { Weed } \\
\text { effectiveness }(\%)\end{array}$} & \multirow{2}{*}{$\begin{array}{c}\text { Crop } \\
\text { dry matter } \\
\text { yield (kg } \\
\left.\text { ha }^{-1}\right)\end{array}$} \\
\hline & $\begin{array}{c}\text { 60 } \\
\text { DAS } \\
\end{array}$ & \begin{tabular}{c|c|}
90 \\
DAS \\
\end{tabular} & $\begin{array}{c}\text { 60 } \\
\text { DAS } \\
\end{array}$ & $\begin{array}{c}\text { 90 } \\
\text { DAS } \\
\end{array}$ & \begin{tabular}{c|c|} 
60 \\
DAS \\
\end{tabular} & $\begin{array}{c}90 \\
\text { DAS } \\
\end{array}$ & \begin{tabular}{c|c|} 
60 \\
DAS \\
\end{tabular} & $\begin{array}{c}90 \\
\text { DAS }\end{array}$ & \\
\hline \multicolumn{10}{|l|}{ Irrigation schedule } \\
\hline $\mathrm{I}_{1}$-Two irrigation (CRI+ active tillering) & 69.0 & 71.0 & 3.49 & 3.73 & 0.85 & 0.84 & 36.4 & 34.7 & 6233 \\
\hline $\mathrm{I}_{2}$-Three irrigation(CRI+ jointing+ booting) & 63.1 & 67.2 & 3.07 & 3.45 & 0.83 & 0.81 & 44.3 & 40.6 & 6529 \\
\hline I3- Four irrigation (CRI+ Active tillering+ booting+ flowering) & 57.7 & 61.7 & 2.76 & 3.04 & 0.76 & 0.71 & 56.0 & 54.1 & 6722 \\
\hline $\begin{array}{l}\text { I4-Five irrigation (CRI+ jointing+ booting+ flowering+ } \\
\text { milking) }\end{array}$ & 55.2 & 61.4 & 2.67 & 3.10 & 0.73 & 0.65 & 61.0 & 59.3 & 6899 \\
\hline $\mathrm{CD}(\mathrm{P}=0.05)$ & - & - & - & - & - & - & - & - & 231 \\
\hline \multicolumn{10}{|l|}{ Herbicides } \\
\hline $\mathrm{W}_{1}$-Weedy check & - & - & - & - & - & - & - & - & 5766 \\
\hline $\mathrm{W}_{2^{-}}$Two hand weeding (20 and 40 DAS) & 100.0 & 100.0 & - & - & - & - & - & - & 7532 \\
\hline 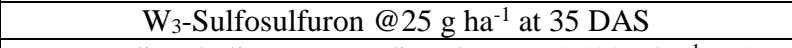 & 60.8 & 66.0 & 2.83 & 3.26 & 0.64 & 0.58 & 60.9 & 58.6 & 6400 \\
\hline W4- Pendimethalin (pre-em) $f b$ WCPL-15@ $400 \mathrm{~g} \mathrm{ha}^{-1}$ at 35 & 65.3 & 70.8 & 3.25 & 3.86 & 0.70 & 0.63 & 49.2 & 46.2 & 6503 \\
\hline
\end{tabular}




\begin{tabular}{|c|c|c|c|c|c|c|c|c|c|}
\hline DAS & & & & & & & & & \\
\hline $\begin{array}{l}\text { W5- Broadway (carfentrazone ethyl } 20 \%+\text { sulfosulfuron } \\
\text { 25\%WG) @ } 100 \text { g a.i. ha }{ }^{-1} \text { at } 35 \text { DAS }\end{array}$ & 70.4 & 76.1 & 4.11 & 5.09 & 0.91 & 0.84 & 32.6 & 28.6 & 7007 \\
\hline 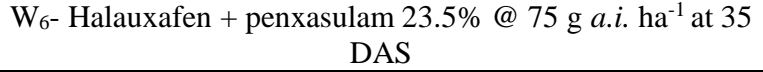 & 65.4 & 70.9 & 3.30 & 3.92 & 0.71 & 0.63 & 48.9 & 45.9 & 6581 \\
\hline $\begin{array}{c}\mathrm{W}_{7} \text { - Halauxafen - methyl } 1.21 \% \mathrm{w} / \mathrm{w}+\text { fluroxypyr @ at } 35 \\
\text { DAS }\end{array}$ & 60.4 & 65.6 & 2.71 & 3.12 & 0.64 & 0.58 & 61.9 & 59.6 & 6181 \\
\hline $\begin{array}{c}\mathrm{W}_{8-} \text { Clodinafop- propargyl 15\% + metsulfuron 1\% @ } 400 \mathrm{~g} \\
\text { a.i. } \mathrm{ha}^{-1} 35 \mathrm{DAS}\end{array}$ & 67.6 & 73.1 & 3.64 & 4.39 & 0.77 & 0.70 & 42.0 & 38.5 & 6798 \\
\hline $\mathrm{CD}(\mathrm{P}=0.05)$ & - & - & - & - & - & - & - & - & 196 \\
\hline
\end{tabular}

\section{Conclusions}

The most commonly reported BLW in wheat are Chenopodium album, Anagallis arvensis, Melilotus indica, Rumex denticulate and Vicia sativa. Among these, Chenopodium album had the highest in number which was followed by Vicia sativa, Anagallis arvensis, Melilotus indica and Rumex dentatus, respectively. Based on the above results it can conclude that decreasing irrigation frequency $\left(I_{1}\right)$ significantly reduces the BLW infestation however, maximum CDMY was achieved with more number of irrigation $\left(\mathrm{I}_{4}\right)$. Among weed management treatments, application of broadway (carfentrazone- ethyl 20\% + sulfosulfuron $25 \%$ WG) $100 \mathrm{~g} \mathrm{ha}^{-1}$ at 35 DAS are the good option for controlling BLW and for better wheat yield.

\section{Acknowledgement}

The author is highly thankful to the competent authority of CSAUAT, Kanpur for providing variable and financial support pertaining to conduct this research.

\section{Conflict of Interest}

Author has declared that no competing interests exist.

\section{References}

1. Ansari MA, Verma SK, Sharma R, Sharma UC, Kumar $\mathrm{G}$, Singh SB. Wild canary grass as influenced by IWM in wheat. Pesticide Research Journal 2009;20(2A):46-49.

2. Deshmukh JP, Kakade SU, Thakare SS, Solanke MS. Weed management in wheat by pre-emergence and premix post-emergence combinations of herbicides. Indian Journal of Weed Science 2020;52(4):331-335.

3. Meena VD, Kaushik MK, Verma A, Upadhayay B, Meena SK, Bhimwal JP. Effect of herbicide and their combinations on growth and productivity of wheat under late sown condition. International Journal of Chemical Studies 2017;5:1512-1516.

4. Rana SS, Badiyala D, Brari P. Evaluation of herbicide combinations for controlling complex weed flora in wheat. Indian Journal of Weed Science 2017;49(4):335340 .

5. Sharma N, Kumar A, Sharma BC, Chand L, Sharma V, Kumar M. Effects of sowing dates and weed management on productivity of irrigated wheat. Indian Journal of Agricultural Sciences 2020;90(3):556-559.

6. Singh A, Yadav AS, Verma SK. Productivity, nutrient uptake and water use efficiency of wheat under different irrigation levels and fertility sources. Indian Journal of Ecology 2010;37(1):13-17.

7. Singh RK, Verma SK, Prasad SK, Singh SB. Effect of metsulfuron-methyl against broad leaf weeds in wheat. Journal of Crop and Weed 2015;11:161-166.

8. Singh RK, Verma SK, Sharma R, Singh SB. Bio-efficacy and selectivity of sulfosulfuron and metribuzin before and after irrigation in wheat under zero-tillage system.
Indian Journal of Agricultural Sciences 2009;79(9):73539.

9. Singh RK, Verma SK, Singh RP. Bio-efficacy of carfentrazone-ethyl + sulfosulfuron in wheat. Indian Journal of Weed Science 2013;45(4):243-246.

10. Singh RP, Verma SK, Kumar S. Weed management for enhancing yield and economics of wheat in Eastern India. Indian Journal of Agricultural Sciences 2020;90(7):13521355.

11. Singh RP, Verma SK, Kumar S, Lakara K. Impact of tillage and herbicides on the dynamics of broad leaf weeds in wheat. International Journal of Agriculture, Environment and Biotechnology 2017;10(6):643-651.

12. Tunio MH, Gao J, Talpur MA, Lakhiar IA, Chandio FA, Shaikh SA et al. Effects of different irrigation frequencies and incorporation of rice straw on yield and water productivity of wheat crop. International Journal of Agriculture and Biological Engineering 2020;13(1):138145.

13. Verma SK, Singh RP, Kumar S. Effects of irrigation and herbicides on the growth, yield and yield attributes of wheat. Bangladesh Journal of Botany 2017;46(3):839845.

14. Verma SK, Singh RP, Singh RK. Effect of application time on efficiency of herbicides in wheat under zero tillage system. Indian Journal of Weed Science. 2007;39(3, 4):197-200.

15. Verma SK, Singh SB, Prasad SK, Meena RN, Meena RS. Influence of irrigation regimes and weed management practices on water use and nutrient uptake in wheat. Bangladesh Journal of Botany 2015;44(3):437-442.

16. Verma SK, Singh SB, Rai OP, Sharma R, Singh G. Effect of cultivars and herbicides on yield and nutrient uptake by weed and under zero-tillage system. Indian Journal of Agricultural Sciences 2008;78(11):985-989.

17. Verma SK, Singh SB, Singh G, Rai OP. Performance of varieties and herbicides on production potential of wheat and associated weeds. Indian Journal of Weed Science 2007;39(1, 2):230-233.

18. Verma SK. Enhancing sustainability in wheat production though irrigation regimes and weed management practices in eastern Uttar Pradesh. The Ecoscan 2014;6:115-119.

19. Yadav DK, Verma SK, Pratap V, Yadav SP, Jaysawal PK. Available nutrients in soil are influenced by planting techniques and weed management options in wheat. International Journal of Chemical Studies 2020;8(4):2718-2721. 